\title{
Susceptibility of Mammalian Cell Line for Isolation of IBDV from Clinical Samples
}

Author(s)

Silva SEL

Ferreira $\mathrm{HL}$

Carvalho BA

Cardoso TC

UNESP (Universidade Estadual Paulista) Depto de Apoio, Produção e Saúde Animal Faculdade de Odontologia - Campus de Araçatuba.

Fellowship by Fundação de Amparo à Pesquisa do Estado de São Paulo, SP, Brasil.

Mail Address

Tereza Cristina Cardoso

Depto de Apoio, Produção e Saúde Animal

Curso de Medicina Veterinária

Rua Clóvis Pestana, 793

16.050-680 - Araçatuba, SP, Brazil.

Fax:+55 186226487

E-mail: tcardoso@fmva.unesp.br

\section{Keywords}

Avibirnavirus, CER cells, diagnosis, double antibody sandwich ELISA, RT/PCR.

\section{Acknowledgement}

The authors would like to thanks Merial Laboratories and FAPESP four the financial support.

This paper was presented in II International Symposium of Infectious Bursal Disease and Chicken Infectious Anaemia, Rauischholzhausen, Germany, 16-20 June 2001

This work was supported by Fundação de Amaparo à Pesquisa do Estado de São Paulo, SP Brasil (98/13717-9).

\section{ABSTRACT}

Susceptibility of chicken embryo related cells (CER) to non-classical IBDV was compared with Vero cells for the same purpose. It was used 20 bursal samples collected from clinical cases of IBDV, positive by histopathological evaluation. After three times infection of CER and Vero cells monolayers, at $6,12,18,24,48,60$ and $72 \mathrm{~h}$ post-infection (PI), extra-cellular and intracelluar IBDV was measured. The extra-cellular amount of IBDV particles was quantified by DAS-ELISA from $6 \mathrm{~h} \mathrm{Pl}$, and increased for both cells studied until $72 \mathrm{~h}$ PI. The IBDV re-isolation performed by infecting chicken embryos showed positive results at all PI studied. The intracellular IBDV RNA was shown by RT-PCR, where all tested samples were positive. However, the cytopathic effect (CPE) caused by IBDV infection was pronounced at $18 \mathrm{~h}$ for Vero and $36 \mathrm{~h}$ for CER cells. The RT-PCR was done to detect IBDV RNA from the bursa samples, where all were positive. Regarding to IBDV isolation, 20\% of samples tested were negative in Vero cells, where all were positive in CER cells infection. The findings allow concluding that CER cell can be a new and appropriated tool for IBDV isolation.

\section{INTRODUCTION}

Avibirnavirus is the causative agent of Gumboro Disease (GD) an economical and important disease to poultry industry. Infectious bursal disease virus (IBDV) whose genome consists of two segments ( $A$ and $B$ ) of double-strand RNA, causes an acute, and contagious disease in young chickens according to Betch et al. (1988), Kibenge et al. (1988) and van der Berg (2000).

Diagnosis of IBDV infections in chickens, eggs or primary cell cultures is extensively employed, although these techniques are not practical as a routine analysis because they are expensive and time consuming (Jackwood \& Jackwood, 1994). In addition, the use of CER cells as an alternative for IBDV field samples isolation, cytopathic effects observation, and virus propagation was not well studied. Furthermore, the appearance of IBDV new serotypes with different degrees of pathogenicity, new biological systems including virus isolation and propagation are necessary, even to produce new kinds of vaccines (Di Fabio et al., 1999; Eterradossi et al., 1999; van der Berg et al., 1991; Cardoso et al., 2000).

This study was carried out to demonstrate that chicken embryo related cells (CER) could be and appropriated tool to isolate IBDV from field samples.

\section{MATERIAL AND METHODS}

\section{Continuous cell line}

The Vero cells passage 58 (African green monkey kidney) was obtained 
Silva SEL, Ferreira HL, Carvalho BA, Cardoso TC from Adolfo Lutz Institute, São Paulo, Brazil. The chicken embryo related cell (CER) was kindly supplied by Dr. Clarice W. Arns, Department of Microbiology and Immunology, University of Campinas, São Paulo, Brazil. The growth medium for CER and Vero cells was used as described by Cardoso et al. (2000) and Ferreira et al. (2003).

\section{IBDV isolation and cytopathic effect (CPE) observation}

Twenty bursa samples, presenting macroscopic signs of IBDV infection, were collected (with technical assistance of Merial Laboratories). The samples were isolated and after adaptation by 3 consecutive blind passages in Vero and CER cells monolayers, the kinetic study was performed according to Cardoso et al. (2000). Briefly, confluent monolayers of both cell cultured in $25 \mathrm{~cm}^{3}$ flasks were infected with the field strain $\left(10^{2.7}\right.$ $E I D_{50} / \mathrm{mL}$ ) at a multiplicity of infection of 5 . The virus was absorbed at $37^{\circ} \mathrm{C}$ in a humidified $\mathrm{CO}_{2}$ incubator for 1 hour. The inoculum was removed and $3 \mathrm{~mL}$ of maintenance medium consisting of minimum essential medium (MEM), antibiotics and $2 \%$ of calf serum was added as recommended by Cardoso et al. (2000). The CPE was graded from $+(25 \%)$ to $++++(100 \%)$ as described before (Lukert \& Davis, 1974). At $6,12,18,24,36,48,60$ and $72 \mathrm{~h}$ after infection the supernatant was removed and used for extra-cellular IBDV detection by DAS-ELISA and embryos infection (Lukert \& Davis, 1974). The RT-PCR and CPE observation were used to detect the cellassociated virus from infected monolayers, either for Vero and CER cells.

\section{Titration of IBDV isolates in specific pathogen free embryonating eggs}

Infected monolayers at $6,12,18,24,36,48,60$ and $72 \mathrm{~h}$ post-infection (PI) were harvest three times and submitted to 10-day-old specific pathogen free embryonating eggs titration and each titre sample (SPF) was calculated by median embryo infectious dose $\left(E_{1 D_{50}} / \mathrm{mL}\right.$ ) method described previously (Reed \& Müench, 1938).

\section{Double antibody sandwich ELISA (DAS- ELISA)}

The DAS-ELISA was applied to detect extra-cellular IBDV according to Cardoso et al. (1998). The specificity was calculated using the non-infected monolayers supernatant and by the use of Newcastle disease virus, reo and influenza A virus detection.
Susceptibility of Mammalian Cell Line for Isolation of IBDV from Clinical Samples

\section{Reverse Transcriptase/Polymerase Chain Reaction (RT-PCR)}

RT-PCR was performed to detect viral RNA from infected monolayers and directly from bursa suspension. First, the respective suspension of bursae prepared according to Cardoso et al. (1998) was submitted to digestion overnight at $4^{\circ} \mathrm{C}$ using lysis buffer containing PBS $0.5 \mathrm{M} \mathrm{NaCl}$ and $20 \mathrm{mg} / \mathrm{mL}$ proteinase $\mathrm{K}$ and after digestion the RNA extraction was performed using Trizo ${ }^{\circledR}$ reagent. Extracted RNA was precipitated using ethanol and dissolved in 90\% dimethyl-sulfoxide (DMSO). The precipitated RNA was re-suspended in 100 $\mathrm{mL}$ DMSO solution and incubated at $98^{\circ} \mathrm{C}$ for $5 \mathrm{~min}$. Briefly, $1 \mathrm{~mL}$ of RNA in DMSO was amplified by RT-PCR using the One Step ${ }^{\circledR}$ RNA PCR Kit (Invitrogen, Life Technologies) according to the manufacture's instructions. One set of primers were used (A3.1 sense 5'-GATTGTTCCGTTTCATACGGA-3' and A 3.2 antisense 5'-AGTGTGCTTGACCTCACTGT-3') as previously described (Tham et al., 1995). These primers amplifies a 309-bp of conservative region on $\mathrm{VP}_{2}$ for IBDV serotype 1 . The amplicons were observed by electrophoresis in $1.5 \%$ of agarose gel with $0.5 \mathrm{mg} /$ $\mathrm{mL}$ ethidium bromide. The specificity of RT-PCR was performed using non-infected bursae samples and the RNA extracted from bovine rotavirus.

\section{Specificity of RT-PCR assay}

Specificity of RT-PCR was performed by using three other RNA viruses (reovirus S1133, Newcastle disease virus and Rotavirus). The amplicons were visualized in $1.5 \%$ agarose gel with $0.5 \mathrm{mg} / \mathrm{mL}$ of ethidium bromide.

Histopathology examination of bursae (HE)

The histopathology analysis was performed as described by Cardoso et al. (1998). Tissues were fixed in $10 \%$ neutral buffered formalin, processed to paraffin and the sections of bursae were cut at 4-5 $\mathrm{mm}$ and stained with haematoxylin and eosin. The score used to classified bursal demage followed the standard procedure described by Tanimura et al. (1995).

\section{Statistical analysis}

The experiment was performed using a completely randomised design schedule and the data (IBDV detected values on tissues - negative control) were submitted to analysis of variance (ANOVA) using the General Linear Model (GLM) of Statistical Analysis System (SAS, 1999). Means were compared by Duncan multiple range test. 


\section{RESULTS}

The IBDV field strains were isolated in CER and Vero cells and after propagated when the CPE was observed. The CPE was characterized by a market granulation of cell cytoplasm, and gradually detached from the monolayers (Figure 1) at 36 hour PI for CER cell, however it was pronounced in Vero cell since at 18 hour PI (Table 1). The extra-cellular IBDV, titrated by embryonating egg infection, demonstrated that at 60 and 72 hour PI high virus titres obtained from CER infected monolayers (Table 1). The cell associated IBDV showed titre of $2.8 \mathrm{EID}_{50} / \mathrm{mL}$, where no virus could be detected from the supernatant of infected CER and Vero cells. On the other hand, extracellular virus had an increase in titre after 36 hour PI detected by DAS-ELISA from the infected Vero and CER supernatant (Table1). The viral RNA from IBDV was confirmed by RT-PCR technique performed on CER and Vero infected monolayers (Figure 2). The IBDV RNA was observed, at all PI when none CPE was observed (Table 2). The CPE involved cell rounding, detachment and lysis (Figure 1). All bursa samples showed severe atrophy of follicles, necrosis and oedema compatible with IBDV infection, and all presented viral RNA of IBDV (Table 2).

Table 1 - Comparison between DAS-ELISA, RT-PCR and embryos infection (EID ${ }_{50} / \mathrm{mL}$ ) techniques to detect IBDV intracellular and extra cellular particles from infected cells, where no differences were observed between techniques.

\begin{tabular}{|c|c|c|c|c|c|c|c|c|}
\hline \multirow{3}{*}{ PI (h) } & \multicolumn{4}{|c|}{ Intracellular virus } & \multicolumn{4}{|c|}{ Extra-cellular virus } \\
\hline & \multicolumn{2}{|c|}{ CER } & \multicolumn{2}{|c|}{ VERO } & \multicolumn{2}{|c|}{ CER } & \multicolumn{2}{|c|}{ VERO } \\
\hline & RT-PCR & $\mathrm{CPE}^{3}$ & RT-PCR & CPE & DAS-ELISA $^{1}$ & EID $^{2}$ & DAS-ELISA & EID \\
\hline 0 & _- & - & _- & _- & & - & - & - \\
\hline 6 & + & _- & + & - & 0.12 & $\leq 2.0$ & 0.13 & $\leq 2.0$ \\
\hline 12 & + & - & + & - & 0.14 & 2.6 & 0.28 & 2.7 \\
\hline 18 & + & - & + & + & 0.23 & 2.8 & 0.32 & 2.8 \\
\hline 24 & + & - & + & + & 0.25 & 3.2 & 0.35 & 3.2 \\
\hline 36 & + & ++ & + & + & 0.34 & 3.9 & 0.37 & 3.4 \\
\hline 48 & + & ++ & + & + & 0.37 & 4.0 & 0.43 & 3.6 \\
\hline 60 & + & ++ & + & + & 0.45 & 4.9 & 0.45 & 4.6 \\
\hline 72 & + & +++ & + & + & 0.49 & 4.8 & 0.48 & 4.8 \\
\hline
\end{tabular}
and methods section.

Table 2- Comparison between histopathology, RT-PCR and cell isolation to diagnosis the IBDV infection in field samples.

\begin{tabular}{|c|c|c|c|c|}
\hline \multirow[b]{2}{*}{ Samples } & \multicolumn{2}{|c|}{ IBDV detection } & \multicolumn{2}{|c|}{ IBDV isolation² } \\
\hline & Histopathology ${ }^{1}$ & RT-PCR & CER & VERO \\
\hline S-1 & ++ & + & ++++ & ++++ \\
\hline $\mathrm{S}-2$ & +++ & + & ++++ & + \\
\hline $\mathrm{S}-3$ & ++++ & + & ++++ & ++ \\
\hline S-4 & ++++ & + & ++++ & + \\
\hline$S-5$ & + & + & + & + \\
\hline S-6 & ++++ & + & +++ & +++ \\
\hline S-7 & ++++ & + & ++++ & +++ \\
\hline$S-8$ & ++++ & + & + & +++ \\
\hline S-9 & ++ & + & ++++ & + \\
\hline$S-10$ & +++ & + & + & +++ \\
\hline$S-11$ & + & + & ++++ & + \\
\hline$S-12$ & ++++ & + & + & - \\
\hline$S-13$ & ++++ & + & + & - \\
\hline$S-14$ & ++++ & + & + & - \\
\hline$S-15$ & ++ & + & + & - \\
\hline$S-16$ & +++ & + & + & ++ \\
\hline S-17 & + & + & +++ & +++ \\
\hline$S-18$ & ++++ & + & ++++ & ++++ \\
\hline S-19 & ++++ & + & + & ++++ \\
\hline$S-20$ & ++++ & + & + & ++++ \\
\hline Positive & ++++ & + & ++++ & ++++ \\
\hline Negative & & _ & - & - \\
\hline $\begin{array}{l}1 \text { - Score } \\
\text { depletion; } \\
\text { lymphoid } \\
\text { from }(+) 25\end{array}$ & $\begin{array}{l}+, \text { minimum lymp } \\
++ \text {, lymphoid deple } \\
\text { ophy and necrosis; } \\
6 \text { to }(++++) 100 \% \text {. }\end{array}$ & $\begin{array}{l}\text { d necrosi } \\
\text { multifoca } \\
\text { ormal. } 2 \text { - } \\
\text { ot detecte }\end{array}$ & $\begin{array}{l}\text { moder } \\
\text { lorrage; } \\
\text { opathic }\end{array}$ & $\begin{array}{l}\text { ymphoic } \\
+ \text {, severe } \\
\text { t gradeo }\end{array}$ \\
\hline
\end{tabular}

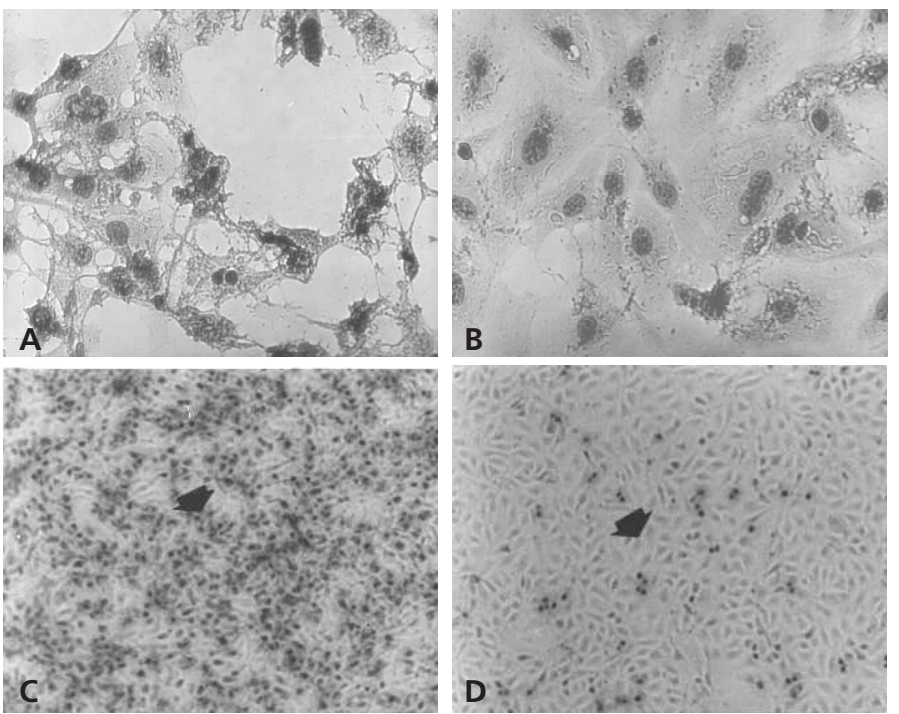

Figure 1 - A) CPE observed in CER cell after IBDV propagation (200X); B) CER uninfected cell; C) CPE observed in Vero cell after IBDV propagation (100X); D) Vero uninfected cell. 
Silva SEL, Ferreira HL, Carvalho BA, Cardoso TC IBDV from Clinical Samples

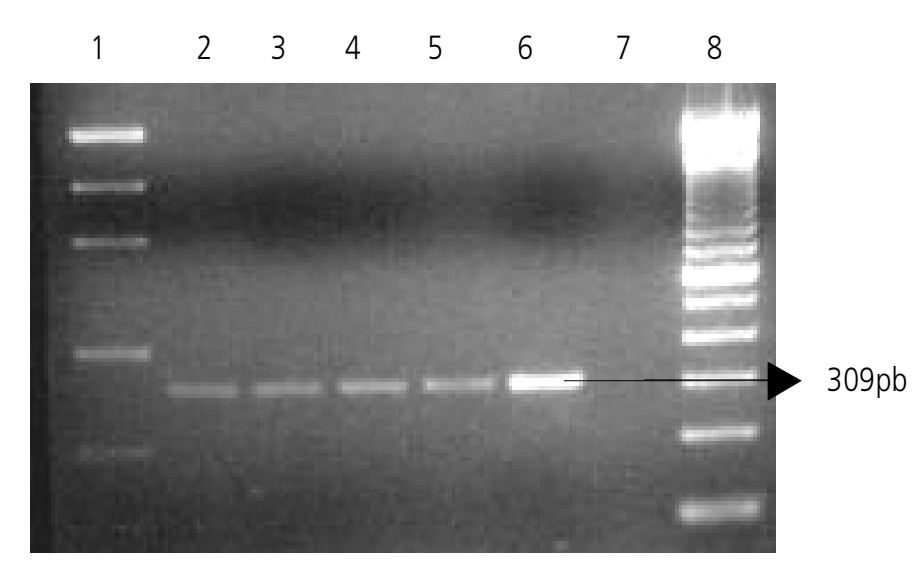

Figure 2 - 1) Low Mass Ladder -5 $\mu$; 2-5) Bursa samples; 6) positive control; 7) negative control; 8) $1 \mathrm{~Kb}$ ladder.

\section{DISCUSSION}

The complexity and the nature of IBDV infection require a diversity approach to virus diagnosis. Molecular virology and avian immunology have made considerable progress and should generate new tools in the near future. For instance, the field IBDV isolation should be essential and decisive for virus identification and genetic studies. The mammalian continuous cells lines would more suitable for this purpose, with several advantages over primary cells line. So far, primary avian cell suspensions may contain exogenous avian virus not found in mammalian cell line, which could interfere with a given test or vaccine production (van der Berg, 2000). Nevertheless, this is the first time of field IBDV isolation in CER cells. These cells have been used and the results demonstrated easier to culture than chicken embryo fibroblast (CEF) (Lukert \& Davis, 1974) for classical strain propagation (Cardoso et al., 2000). In this study the CPE observed at 18 hour PI from infected Vero monolayers was different from CER infection, when the CPE could be observed at 36 hour PI. The BGM-70 cells (baby monkey kidney cell line) has been used for virus neutralization test also which can be an advantage over CER cells, however neutralization assay should be tested in a near future (Jackwood et al., 1986). Actually, the CPE occurred during the first passage at 72 hour PI, however 2 more blind passages were done to certify IBDV propagation. Thus, the time required for extracellular virus detection was almost the same for CER and Vero cell, according to previously studies (Cardoso et al., 1998; Cardoso et al., 2000; Ferreira et al., 2003). The cell associated virus detected by eggs inoculation demonstrated the high virus levels at 60 hour PI and
72 hour PI, showed by CER and Vero monolayers infection. The RT-PCR detected IBDV RNA from infected monolayers and respective supernatant when none CPE was observed. Therefore, in this study it could be possible to confirm in early periods virus replication performing RT-PCR, which can improve faster epidemiological study. The RT-PCR applied in tissue samples positive to IBDV infection by histopathology analysis, showed viral RNA amplification before IBDV isolation (Tham et al., 1995). Finally, the development of safe laboratory techniques that could isolate and propagate IBDV field strains might be considerable. Our results showed the capacity of CER cell to isolate IBDV from all clinical samples and respective propagation, as already demonstrated for classical virus, where $20 \%$ was negative for Vero cells system. Nevertheless, this is the first time of field IBDV isolation in CER cells and could be considered useful tool for routine diagnosis of the disease.

\section{REFERENCES}

Becth $H$, Muller $H$, Muller HK. Comparative studies on structural and antigenic properties of the two serotypes of infectious bursal disease virus. Journal of General Virology 1988; 69:631-640.

Cardoso TC, Sousa RLM, Alessi AC, Montassier HJ, Pinto AA. A double antibody sandwich ELISA for rapid diagnosis of virus infection and to measure the humoral response against infectious bursal disease on clinical material. Avian Pathology 1998; 27:450-454.

Cardoso TC, Rahal P, Pilz D, Teixeira MCB, Arns CW. Replication of classical infectious bursal disease virus in the chicken embryo related cell line. Avian Pathology 2000; 29:213-217.

Di Fabio J, Rossini, LI, Eterradossi, N, Toquin, N, Gardin, Y. Europeanlike pathogenic infectious bursal disease viruses in Brazil. Veterinary Record 1999; 145:203-204.

Eterradossi N, Arnauld C, Tekaia F, Toquin D, Le Coq H, Rivallan G, Guittet M, Domenech J, van der Berg TP, Skinner MA. Antigenic and genetic relationship between European very virulent infectious bursal disease virus and an early West African isolate. Avian Pathology 1999; 28:36-46.

Ferreira HL, Pilz D, Mesquita LG, Cardoso TC. Replication of bronchitis infectious virus in the chicken embryo related cell line. Avian Pathology 2003; 32:409-413.

Jackwood DH, Saif YM, Hudges HJ. Replication of infectious bursal disease virus in continuous cell lines. Avian Disease 1986; 31:370-375.

Jackwood DH, Jackwood RJ. Infectious bursal disease: molecular differentiation of antigenic subtypes among serotype 1 viruse. Avian Diseases 1994; 38:531-537.

Kibenge FS, Dhillon AS, Russel RG. Biochemistry and immunology 
of infectious bursal disease virus. Journal of General Virology 1988; 69:1757-1775.

Lukert PD, Davis RB. Infectious bursal disease virus: growth and characterisation in cell cultures. Avian Diseases 1974; 18:243-250.

Reed LJ, Muench H. A simple method of estimating fifty per cent end points. American Journal of Hygiene 1938; 27, 493-497.

SAS (Statistical Analysis System). Procedures Guide, version 6, $3^{\text {rd }}$ ed. Cary NC. Statistical Analysis System Institute, Inc. 1999.

Tanimura N, Tsukamoto K, Nakamura K, Narita M, Maeda M. Association between pathogenicity of infectious bursal disease virus and viral antigen distribution detected by immunohistochemistry. Avian Diseases 1995; 39:9-20.

Tham KM, Young LW, Moon CD. Detection of infectious bursal disease virus by reverse transcription-polymerase chain reaction amplification of the virus segment A gene. Journal of Virological Methods 1995; 53:201-212.

van der Berg TP. Infectious bursal disease. Avian Pathology 2000; 29:175-194.

van der Berg TP, Gonze M, Meulemans G. Acute infectious bursal disease in poultry: isolation and characterization of a highly virulent strain. Avian Pathology 1991; 20:133-143. 